\title{
The Early-Middle Pleistocene environmental and climatic change and the human expansion in Western Europe: A case study with small vertebrates (Gran Dolina, Atapuerca, Spain $)^{\star}$
}

\author{
G. Cuenca-Bescós ${ }^{\mathrm{a}, *}$, M. Melero-Rubio $^{\mathrm{a}}$, J. Rofes ${ }^{\mathrm{a}}$, I. Martínez ${ }^{\mathrm{b}}$, J.L. Arsuaga ${ }^{\mathrm{c}}$, H.-A. Blain ${ }^{\mathrm{d}}$, \\ J.M. López-García ${ }^{\mathrm{d}}$, E. Carbonell ${ }^{\mathrm{d}}$, J.M. Bermudez de Castro ${ }^{\mathrm{e}}$ \\ ${ }^{a}$ Paleontologia, Aragosaunus-IUCA, Facuitad de Ciencias, Universidad de Zaragoza. E-50009 Zaragoza, Spain \\ b Paleontología. Departamento de Geología. Universidad de Alcalá de Henares. 28801 Alcalá de Henares. Centro de Investigación (UCM-ISCIII) sobre \\ Evolución, y Comportamiento Humanos, c/Sinesio Delgado, 4, Pab. 14, E-28029 Madrid, Spain \\ ${ }^{c}$ Centro de Investigación (UCM-ISCIII) sobre Evolución, $y$ Comportamiento Humanos, c/Sinesio Delgado, 4, Pab. 14, E-28029 Madrid, Spain \\ ${ }^{d}$ Institut de Paleoecologia Humana $i$ Evolució Sociai, Àrea de Prehistòria, U. Rovira $i$ Virgill, Plaça Imperial Tarraco 1, E-43005 Tarragona, Spain \\ ¿Centro Nacional de Investigación sobre la Evolución Humana, Avenida de la Paz 28, E-\$9๑4 Burgos, Spain
}

Keywords:

Environmental change

Early-Middle Pleistocene

Human population impact

Atapuerca

Western Europe

Jordan Valley

\begin{abstract}
A B S T R A C T
The dispersal of hominins may have been favored by the opening of the landscape during the Early-Middle Pleistocene transition (EMP) in Western Europe. The structure of the small-vertebrate assemblages of the archaeo-paleontological karstic site of Gran Dolina in Atapuerca (Burgos, Spain) shows important environmental and climatic changes in the faunal succession, across the Matuyama-Brunhes boundary at $780 \mathrm{ka}$. These changes are interpreted to indicate impoverishment of the forests, along with an increase in dry meadows, and open lands in general that entailed a tendency towards the loss of diver sity in small-ver tebrate communities above the EMP. We evaluate variation in diversity of the faunal succession of Gran Dolina using Shannon's Second Theorem as an index of ecosystem structure. The long cultural-stratigraphic sequence of Gran Dolina during the EMP is somewhat similar in its completeness and continuity to that in the locality of Gesher Benot Ya'aqov in the Upper Jordan Valley. We also evaluate related data including faunal and floral (pollen) succession. Both localities present cold, dry and humid, warm fluctuations at the transition between the Early and the Middle Pleistocene. Comparisons between these sites present opportunities to understand large-scale climatic changes.
\end{abstract}

\section{Introduction}

The climate change around the Early-Middle Pleistocene transition in the Upper Jordan Valley between ca. 800 and $700 \mathrm{ka}$ is the main focus of this Special Issue in which we are trying to establish correlations and make comparisons with what occurred in distant regions. Overall, we hope to assess the impact of climate change on the environment, and on hominins, and its potential for predicting future scenarios. The sediments of the Early-Middle Pleistocene locality of Gesher Benot Ya'aqov (GBY), in the Jordan Valley, provides a good stratigraphic sequence for correlating with the events recorded in the westernmost part of Europe, particularly the locality of Gran Dolina in Atapuerca, Burgos, north of Spain. The Early to Middle Pleistocene sediments of GBY are located at the shores of the paleo-Lake Hula, in the Dead Sea Rift (Goren-Inbar et al., 2000; Alperson-Afil et al., 2009; Spiro et al., 2009, 2011). The fossil vertebrates at GBY derive primarily from the upper half of the section, above the Matuyama-Brunhes boundary. Here, faunal assemblages are dominated by Microtus guentheri, the Levant vole (Goren-Inbar et al., 2000). The species $M$. guentheri is an extant arvicoline rodent that lives in colonies in the eastern Mediterranean, preferring dry grasslands with sparse vegetation on well drained soil, riverbanks and grassy meadows (Çolak et al., 1998). It is considered a pest in Israel's agricultural fields (Cohen-Shlagman et al., 1984). The ecologic and isotopic studies of molluscs at GBY indicate that the EMP transition coincides with an environmental 
change from a relatively cold dry climate towards a warmer temperate subtropical climate in this region (Almogi-Labin et al., 2011; Spiro et al., 2009, 2011).

Global climate changes of the past can be studied using the paleontological and archaeological record in stratigraphic sequences of different localities throughout Eurasia. Dating the sequences on the basis of biostratigraphic, radiometric, or paleomagnetic readings is essential for establishing correlations among remote regions. Moreover, understanding the causal relationship between changes in climate and the natural environment, and their impact on the human population, represents pressing issues of global importance.

Our short-term objectives are to detect climate changes through the ca. 800 k.yr. sequence at the karstic site of Gran Dolina in the Sierra de Atapuerca, Burgos (northern Spain) by studying the smallvertebrate faunal assemblages and the faunal succession throughout the Gran Dolina stratigraphic sequence, with special emphasis across the Early-Middle Pleistocene transition represented at layers Gran Dolina 6 to Gran Dolina 8-9 (TD6-TD8-9). We concentrate mainly on the small vertebrates and refer to studies of large mammals and pollen for discussion. In concentrating on small vertebrates, we expect to track changes that could have had an impact on the hominin populations during the Early-Middle Pleistocene transition in Western Europe. Such influences could have impacted dispersal from the Mediterranean areas to the north of Europe, as well as the correlations of events between these two different regions, the Jordan Valley and the Atapuerca sites. We also briefly consider the implications of published data on large mammal faunal assemblages and pollen data for our results.

\section{The Atapuerca sites}

The archaeological and paleontological sites of Atapuerca, located near the city of Burgos on St.James's Way in northern Spain (Fig. 1), contain the world's most extraordinary accumulation of Pleistocene fossil humans and related stone artifacts (e.g., Carbonell et al., 1995, 1999, 2005; Arsuaga et al., 1997, 1999a, b; Bermúdez de Castro et al.,1997,2004; Arsuaga and Martínez, 2004; Martinez et al., 2004).

The Atapuerca sites are part of at least two cave complexes known as the Sierra de Atapuerca karst system (Ortega Martínez, 2009). The Sierra is a small Mesozoic-core hill connected to the Iberian Range, which constitutes a scarcely pronounced fossil relief in the middle of the nearly flat, Neogene sediments of the Bureba Corridor, which connects the Ebro and Duero Basins (Mediterranean and Atlantic realms). For a detailed geomorphologic study see Benito (2004) and Benito-Calvo et al.
(2008). The Sierra de Atapuerca has three main cave systems (Fig. 1). From east to west these are El Mirador, Cueva Mayor, and Trinchera del Ferrocarril (La Trinchera). The first has provided one of the best Holocene sequences in the Iberian Peninsula (Vergés et al., 2002). The second comprises the sites of Sima de los Huesos, Galería del Sílex, Galería Baja-Sima del Elefante (note that Sima del Elefante outcrops at the railway trench, and is thus one of the "Railway" or Trinchera localities), Galería del Silo, Galería de las Estatuas and El Portalón. The fossils of Sima de los Huesos represent one of the most important collections of fossil human remains from the Middle Pleistocene (Arsuaga et al., 1997; Martinez et al., 2004; Bischoff et al., 2007). The El Portalón sequence includes the end of the Upper Pleistocene and a good part of the Holocene (López-García, 2008). The third, Trinchera del Ferrocarril, is an ancient railway cutting that exposed several fossiliferous caves, comprising the sites of Gran Dolina, Trinchera Penal and Zarpazos-Galería-Tres Simas. The sequences of Gran Dolina and Sima del Elefante have the oldest hominin record in Europe, c.a. 0.8-1.4 Ma (Bermúdez de Castro et al., 1997, 2004; Carbonell et al., 1995, 1999, 2008; Berger et al., 2008). The Galería-Zarpazos system has provided human remains from the Middle Pleistocene (c.a. $0.5 \mathrm{Ma}$ ), allowing correlation of these levels with Sima de los Huesos (Arsuaga et al., 1999a, b; Bischoff et al., 2007). The conspicuous red cave sediments from the railway trench have attracted the attention of archaeologists since the middle of last century. Nevertheless, it was not until the 1960s that the enterprise of archaeological studies was initiated by Clark, Straus and Apellániz (Ortega Martínez, 2009). The first work in the palaeontology of the Sierra was done by Torres in 1976, consisting of an investigation into the fossil Ursidae from Spain (Torres, 1988). It was Emiliano Aguirre who in 1978 set in motion the Atapuerca Project that continues today (Aguirre, 1995, 2007).

The sedimentary infilling of the cave of Gran Dolina represents the longest stratigraphic sequence of the Sierra de Atapuerca sites, comprising 18-19 m of outer cave-filling sediments, actually divided into 19 stratigraphic levels (Fig. 2). The Gran Dolina site is famous for having delivered some of the oldest hominin remains of Western Europe in Gran Dolina level 6 (Aurora stratum, Carbonell et al., 1995, 1999, 2005), which, in 1997, were recognized as a new species, Homo antecessor, ca. 800 ka (Bermúdez de Castro et al., 1997, 2004; Carretero et al., 1999). Moreover, the evidence of lithic industries throughout the long vertical section suggests frequentation on the part of hominins from the latest Early Pleistocene levels Gran Dolina 4, 5, and 6 to the Middle Pleistocene level Gran Dolina 10.

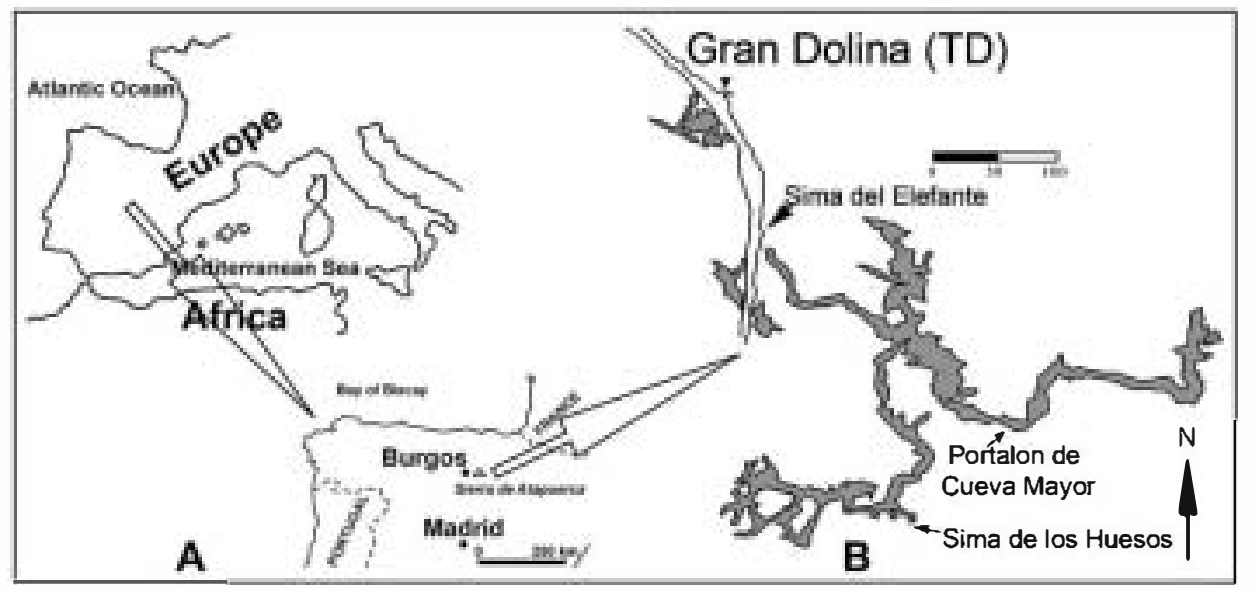

Figure 1. A Iocation of the Sierra de Atapuerca (Burgos, Spain): Latitude: $42^{\bullet} 22^{\prime} \mathrm{N}$. Longitude: $3^{\circ} 38^{\prime} \mathrm{W}$. B. Plan view of the cave system and the Trench of the Ferrocarril (La Trinchera) of the Atapuerca Sites. 


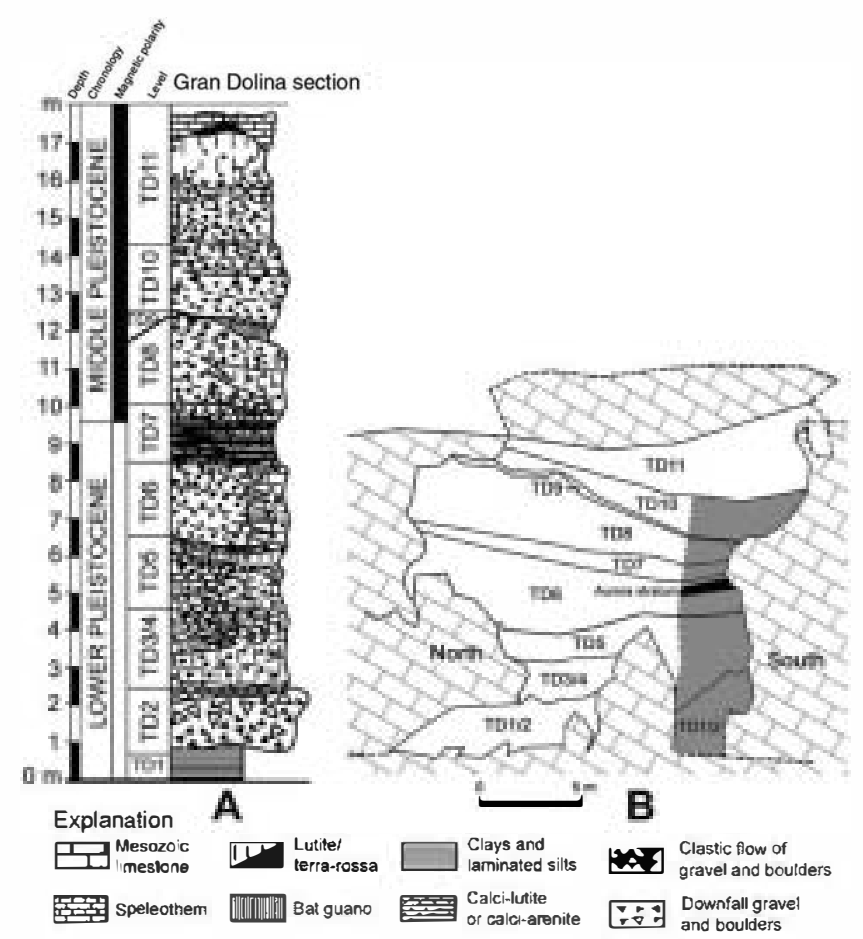

Figure 2. A. Synthetic stratigraphic column of the cave sequence of Gran Dolina (from Parés and Pérez-Gonzâlez, 1995). B. The topography of the infillings (according to $R$. Pérez Martinez in Huguet Pàmies [2007]. The excavation-test to the South(Trinchera Dolina Sondeo Sur [TDS, in grey]), is indicated, as well as the Aurora stratum where the fossils of Homo antecessor were found (in black).

\section{Materials and methods}

In this research, we assume that, in the course of the expansion of the genus Homo in Europe during the nearly 200 k.yr. (800-600 ka) that separate the Early Pleistocene from the Middle Pleistocene, the European landscape underwent a general opening that favored the general expansion of the Homo heidelbergensis species. We hypothesize that, its predecessor, Homo antecessor, was confined to the Mediterranean areas by the dense covered lands (Cuenca-Bescós et al., 2005). The small-mammal fossil assemblages of the Gran Dolina stratigraphic sequence show a general trend towards the opening of the landscape during the Early to Middle Pleistocene transition (EMP).

Analyses of the species diversity of small, non-flying mammals are common in ecology for the description of present-day communities (McCain, 2004; Rowe, 2009). The determinants of the species richness of present-day non-flying small-mammal associations (Rowe, 2009) are limited by numerous variables, including temperature, precipitation, productivity, habitat heterogeneity, area and restrictions peculiar to the distribution of the species, as well as the mid-domain effect or topography (McCain, 2004). According to McCain (2004), the geometric constraints of montane topography appear to influence the diversity pattern of small mammals, although climatic conditions (rainfall and temperature regime) are correlated with the pattern of species richness. The topography of the area around the Gran Dolina cave and the Sierra de Atapuerca seems to have been very similar from the Early Pleistocene to the present, apart from the fact that the rivers near the caves of Atapuerca, the Arlanzon and the Pico, are now probably about $100 \mathrm{~m}$ lower than they were during the Early-Middle Pleistocene (Benito, 2004), when the difference in altitude between the river valley and the cave mouths was some $10-50 \mathrm{~m}$ less (Fig. 3). As such, we assume that the changes in the diversity and structure of the small-vertebrate assemblages of Gran Dolina are related to taphonomy, climate changes and changes in the landscape of the Sierra de Atapuerca and vicinity during the period of time when the death assemblages were accumulating inside the cave.

The role of small-mammal fossil assemblages in reconstructing the past environments during the Early-Middle Pleistocene transition

An assessment of the structure of the associations of fossil small vertebrates from the Pleistocene site of Gran Dolina by means of a statistical description has previously only been carried out for the small-mammal associations (López Antoñanzas and Cuenca-Bescós, 2002; Cuenca-Bescós et al., 2005), including chiropterans. The habitat change detected with small mammals by Cuenca-Bescós et al. (2005) reported that levels TD5 and TD6 have higher habitat diversity than TD8, TD8-9 and TD10 (Fig. 4). The open-land, wet and dry habitats have by far the best representation in the whole sequence. Within the open-land habitat, TD5-TD6 have less than 50\% open-dry land dwellers but more than 50\% open-wet land dwellers, and TD8, TD8-9, TD10 have an increase in the open-dry land dwellers to almost $100 \%$ at the

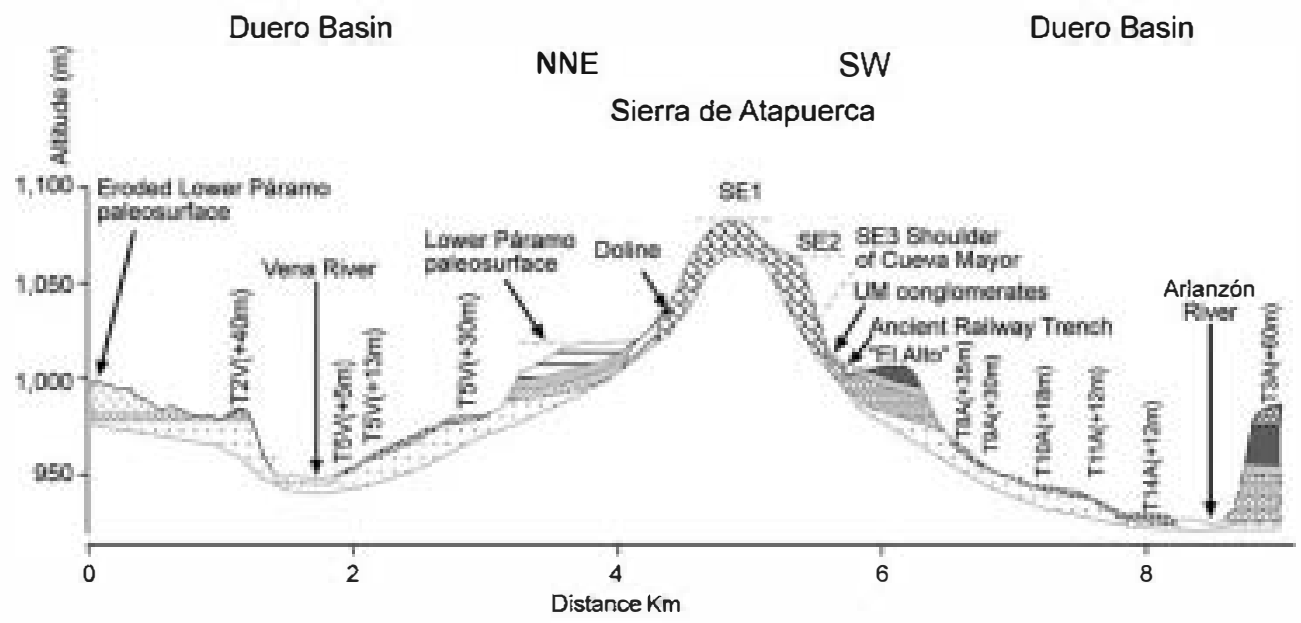

Figure 3. Altitudinal profile of the Sierra de Atapuerca, Burgos, Spain (modified from Benito, 2004: Figure 3.18). 


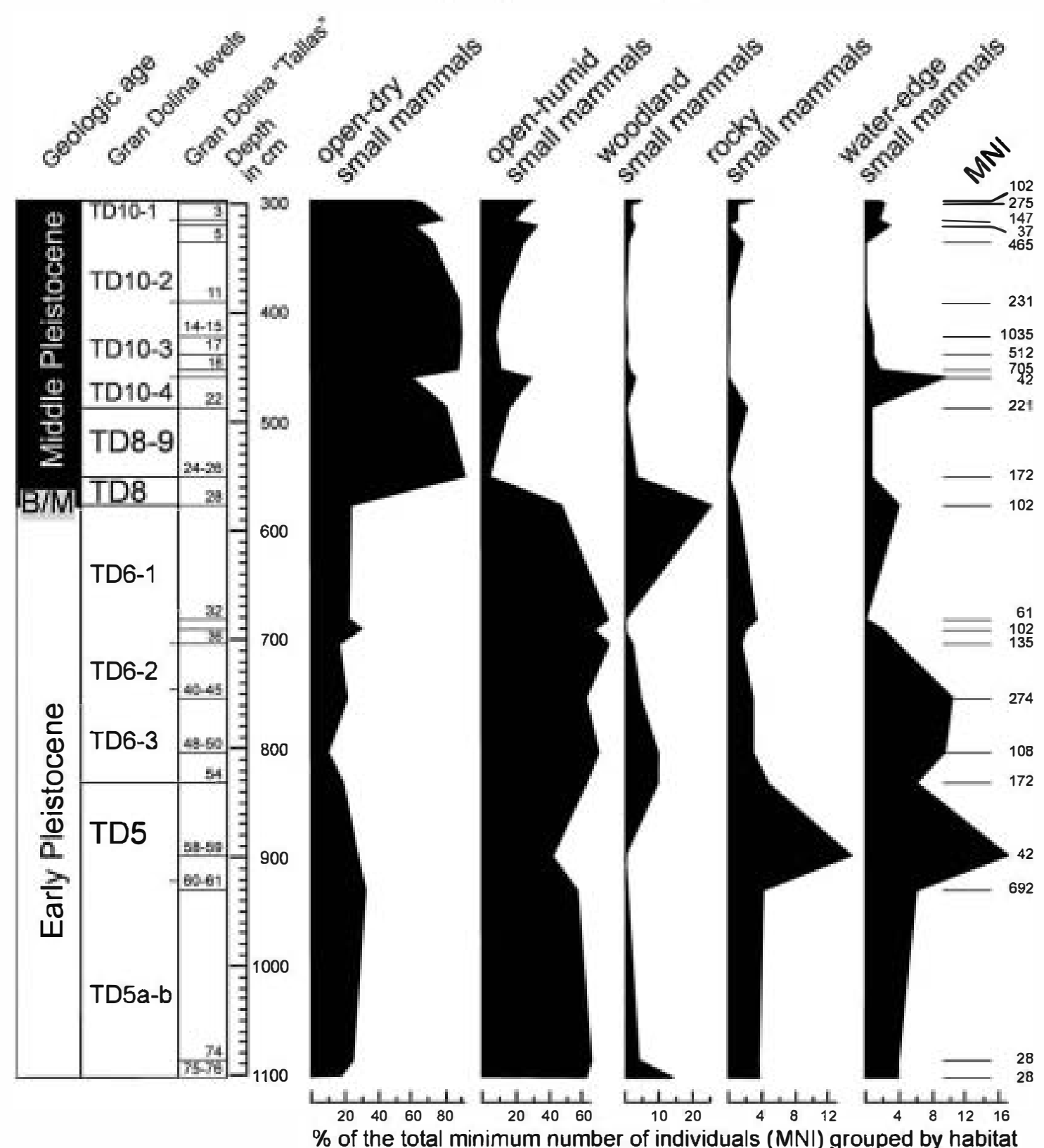

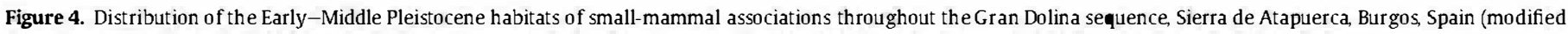
from Cuenca-Bescós et al., 2005). Level TD7 does not appear in the figure because the number of specimens was insufficient for the statistical analysis.

upper part of Gran Dolina, while the open-wet habitat decreases to its minimum rates (Fig. 4).

The Pleistocene small-vertebrate fossil record is characteristically multivariate because each separate taxon in the fossil record provides one variable. Moreover, this record is multiscale, involving both temporal (biostratigraphy, sampling resolution) and spatial scales (biogeography, unique sections, composite sections, multiregional sections), because data from different levels at different localities and/or sections can be analysed separately. As a result, it has the potential to yield a wealth of palaeoenvironmental information. Although calibrations of small-vertebrate fossil data in terms of environmental variables can be made in various ways, all techniques for making palaeoenvironmental reconstructions from such data depend upon accurate taphonomic studies as well as the actualistic assumption that the present is the key to the past, and most researchers utilize data from contemporary biological, ecological, and biogeographical studies (Pokines, 1998; López Antoñanzas and Cuenca-Bescós, 2002; Cuenca-Bescós et al., 2001, 2008, 2009).

Although continuous or semi-continuous fossil records extending more than a few thousand years in the Early-Middle Pleistocene transition (EMP) are rare, the insights they provide into past communities and environments are especially valuable. The case of Gran Dolina, in the Sierra de Atapuerca, is a special one because this site provides a semi-continuous record of the fauna, flora and human presence during the EMP. Another example of a semi-continuous archaeological and paleontological record in the Early-Middle Pleistocene transition is the site of Gesher Benot Ya'aqov (GBY), in Israel (Goren-Inbar et al., 2000; Rabinovich et al., 2008; Sharon et al., 2011). 
Taphonomy

The large accumulations of small mammals in the different levels of the locality of Gran Dolina stem mostly from fossil pellets which enter the cave with sediment and are allochthonous in origin (Fernández Jalvo and Andrews, 1992). Recent taphonomic observations of the collections of small vertebrates at Gran Dolina corroborate this hypothesis. Given the type of digestion and the breaks in the fossils, these are due mostly to nocturnal birds of prey such as the barn owl and the eagle owl, opportunists that hunt a broad range of prey (Bennàsar Serra, 2010).

\section{Species count}

Since the early 1990s, the current Atapuerca team has been carrying out excavations, in various phases, in all the stratigraphic sequences of the caves of the Sierra de Atapuerca. Microfauna were separated from the sediment with sieves of $0.5 \mathrm{~mm}, 5 \mathrm{~mm}$ and $10 \mathrm{~mm}$ mesh aperture size. The Gran Dolina Sondeo South (TDS, a large testing borehole, of ca. $9 \mathrm{~m}^{2}$, carried out between 1993 and 1999 for evaluating the richness of the locality) has furnished a great number of small-vertebrate remains obtained with the washing-sieving technique. The product of this technique consists of several thousand samples, accurately kept in separated plastic bags and consisting mainly of small limestone fragments and the fossil remains of small vertebrates. Sometimes seeds (Celtis) and invertebrate fragments (Gasteropoda) also appear. Each plastic bag was duly labelled with an abbreviation indicating the site and stratigraphic level from which it came, the archaeostratigraphic level ( $T$ ), the excavation grid unit, the depth $(Z$, in metres above sea-level), and the year in which the remains were recovered. The washing-sieving technique allowed recovery an important collection of small vertebrates (Cuenca-Bescós et al., 1995, 1998, 1999, 2001, 2005; Blain et al., 2008, 2009; Rofes and Cuenca-Bescós, 2009a, b).

The species richness and the abundance of small mammals, reptiles and amphibians were reviewed for the entire stratigraphic column of the locality of Gran Dolina, at the Gran Dolina Sondeo South.

The small-vertebrate assemblage comprises the sum of the individuals from each taxon identified in a sample. As explained previously, the sample is the result of collecting a spatio-temporal unit equivalent to the sediment contained in an archaeostratigraphic level or a given stratum (labelled $\mathrm{T}$ in sample-labels and in Fig. 5) of volume $x \times y \times z$. The excavation grid is the area (space $=$ area $=x \times y$ ), and the depth or thickness is time (time $=$ thickness $=$ upper $\mathrm{z}-$ lower $\mathrm{z}$ ). The archaeostratigraphic levels are arbitrary divisions of the stratigraphic level, because their depth is determined by those digging, whereas the stratigraphic level is defined in terms of its lithological composition and geometry. The time scale is provided by the different biostratigraphic, palaeomagnetic and radiometric dating of Gran Dolina (Carbonell et al., 1995; Parés and Pérez-González, 1995; Cuenca-Bescós et al., 1999, 2001, 2010; Falguères et al., 1999; Cuenca-Bescós and García, 2007; Berger et al., 2008).

\section{Taxonomy and systematic palaeontology}

Most of the fossil remains consist of postcranial bones and isolated teeth. The mammals were classified in accordance with works by Chaline (1972), van der Meulen (1973), Alcalde et al. (1981),

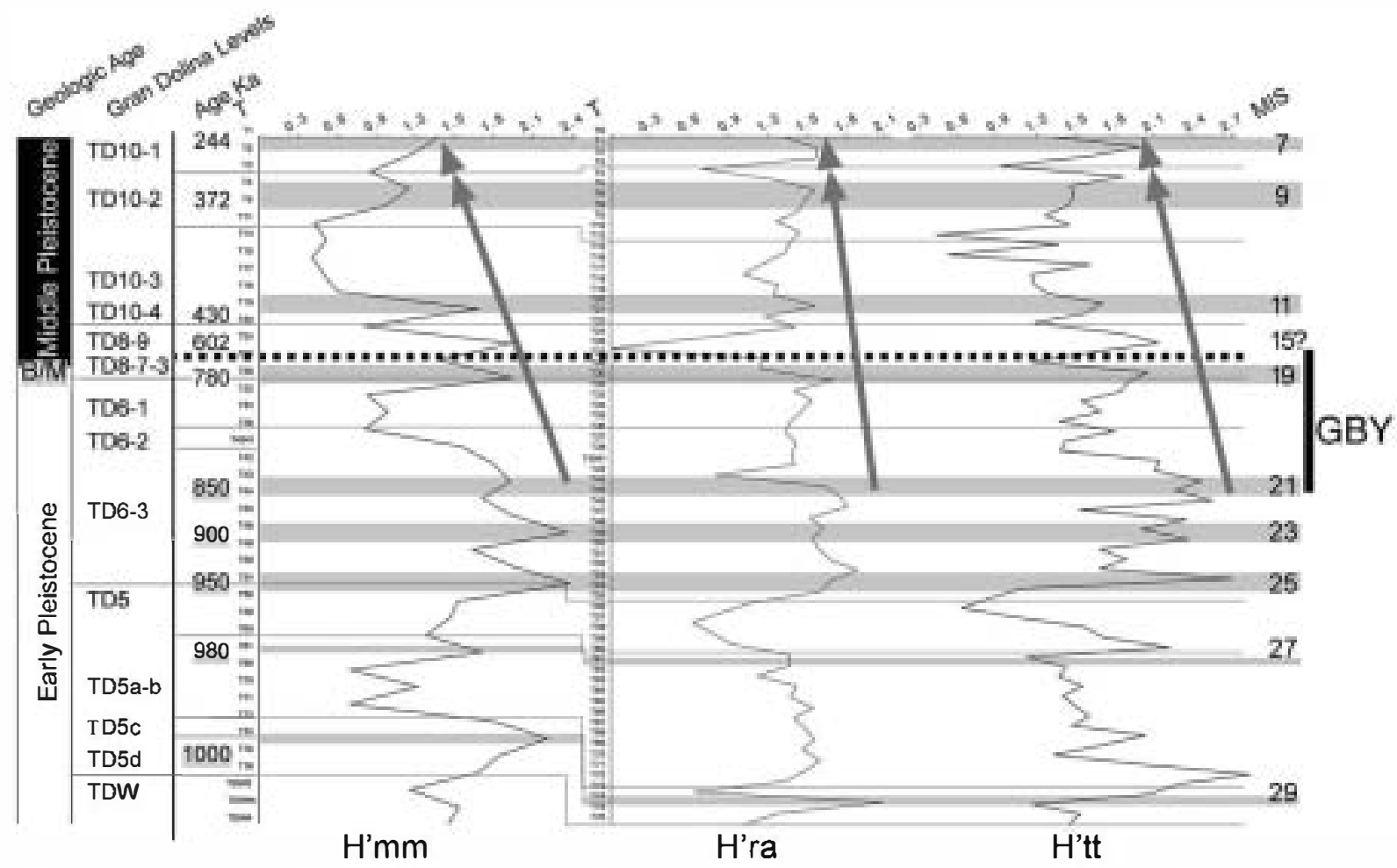

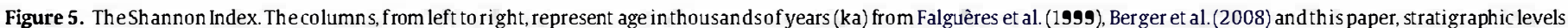

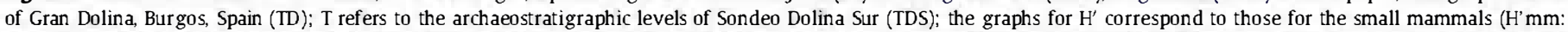

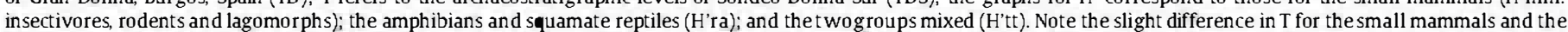

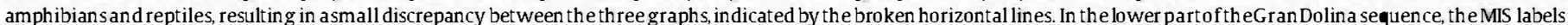

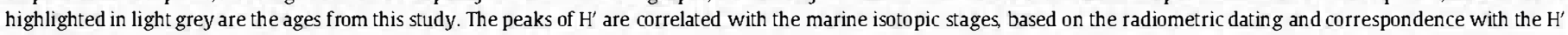

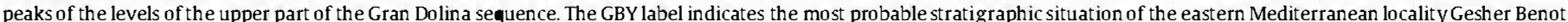
Ya'aqov, Israel (Goren-Inbar et al., 2000; Spiro et al., 2009, 2011). As in Fig. 4, the level TD7 has insufficient number of specimens for the analysis. 
Cuenca-Bescós (2003), and Cuenca-Bescós et al. (1995, 1999). The amphibian and reptile fragments were identified following the general criteria given by Böhme (1977), Bailon (1999), Esteban and Sanchiz (1985, 1991), Holman (1998) and Gleed-Owen (2000) for Anura, and Bailon (1991), Szyndlar (1984) and Blain (2005) for Squamata. The taxonomy has been improved by the recent works of identification and analysis of amphibians and reptiles (Blain et al., 2008,2009 ) and a closer study of the systematic and taxonomy of insectivore mammals, such as the recent definition of Dolinasorex glyphodon (Rofes and Cuenca-Bescós, 2009a), a new venomous giant insectivore previously designated as Beremendia (CuencaBescós et al., 1999; López Antoñanzas and Cuenca-Bescós, 2002) or Soricinae indet. (Cuenca-Bescós and Rofes, 2007). The taxonomic status of some species of rodents is still in preparation.

For counting the minimum number of individuals, we followed the criteria of Cuenca-Bescós et al. $(2005,2009)$ and Blain et al. (2008, 2009).

\section{Analysis}

In this paper, the structure of fossil communities is analysed in statistical terms, using Shannon's Second Theorem (Shannon and Weaver, 1949) because Shannon's expression $\left(\mathbf{H}^{\prime}\right)$ is a function that meets the desirable conditions of an index of diversity.

\section{Shannon's formula.}

The main formula used to describe diversity is:

$$
H^{\prime}=-k \sum \text { pilnpi }
$$

Where $p_{i}=n_{i} / N, n i$ is the number of specimens per taxon, and $N$ is the total number of individuals in the sample, such that $\Sigma n_{i}=N$. The terms of the summation are $\Sigma$, from $i$ to $S$ is equal to the total number of taxa of insectivores, rodents, lagomorphs, reptiles and amphibians identified. The indices were calculated using Excel (a Microsoft Office application) and PASГ (Hammer et al., 2001), obtaining the same results.

\section{Results}

In total we analyzed 71 samples corresponding to 71 archaeostratigraphic levels of the Gran Dolina site sequence. A total of 49 taxa were identified, including 28 mammals and 21 amphibians and reptiles; from a total of 12,359 individuals, 6205 are mammals and 6154 are amphibians and reptiles (Table 1).

\section{Shannon distribution}

The Shannon Diversity Indexprovides one of the best reflections of the structure of a community, in comparison with other indices including those of Simpson, Berger-Parker, evenness indices, etc. (Hammer et al., 2001).

The distribution of the Shannon index, based on only the smallmammal inventory from Gran Dolina Sondeo South plus the excavations at Gran Dolina level TD4W, fluctuates in the course of the sequence (Fig. 5), shown previously by López Antoñanzas and Cuenca-Bescós (2002). Nonetheless, the continuing work of extraction and analysis of new samples has allowed us to provide a better outline of this distribution, producing slightly different results in which the fluctuations become more marked, obtaining more peaks of equilibrium-dominance. The fluctuations of the Shannon diversity index show alternating peaks of high Shannon diversity index values or lower Shannon values. Here we assume that high $\mathrm{H}^{\prime}$ are related to warm, humid conditions, while low $\mathrm{H}^{\prime}$ are related to cooler, dry conditions.
There is an important decrease in the Shannon index related to a loss of diversity slightly before the Matuyama-Brunhes boundary that may be correlated with dry and cold conditions. On the other hand, high Shannon values and peaks are correlated with Marine Isotope Stages (MIS) 29-7 (Fig. 5). An important hiatus in Gran Dolina 8 is reflected in the sequence by the lack of MIS 18-15 (see Cuenca Bescós et al., 1998). The correspondence of high diversity peaks to warm MIS concurs with radiometric dating, at least for the upper part of the Gran Dolina sequence (Falguères et al., 1999; Berger et al., 2008).

In the Early-Middle Pleistocene transition a substantial loss of diversity can be observed some 200 k.yr. after the Matuyama-Brunhes boundary (MMB) (Fig. 5) at the level of Gran Dolina 8-9 (TD8-9). The transition appears to be more marked in mammals than in reptiles and amphibians, but significantly affects both groups of vertebrates (H'mm, H'ra, and $\mathrm{H}^{\prime} \mathrm{tt}$, respectively [Fig. 5]. This loss of diversity coincides with the environmental change illustrated by the habitat indices by Cuenca-Bescós et al. (2005), as is shown in Fig. 4. Likewise, above the MMB that occurs at Gran Dolina level TD7, and between TD8 and TD8-9 there is an important faunal change. This faunal change represents the last appearance data of Early Pleistocene faunal assemblages (i.e., Mimomys savini, Stenocranius gregaloides, Pliomys episcopalis and the giant venomous shrews among other small mammals) and the first appearance of Middle Pleistocene faunas (i.e., Arvicola aff. sapidus, Microtus agrestis jansoni, Pliomys lenki) see Cuenca-Bescós and García (2007).

\section{Discussion}

\section{Evolution of habitats of the Gran Dolina sequence}

Evidence for woodland, rocky small mammals and water environments is scarce and our analyses indicate pulses and hiatuses in the sequence. Open habitats predominate. Just above the Matuyama-Brunhes boundary the habitats are relatively humid and forested, but these change to dry and open lands slightly after this paleomagnetic event (Fig. 4). These changes probably indicate a colder climate. Of particular note is the general demise of these habitats following TD8-9 up through the end of the sequence. An environmental change took place between levels TD8 and TD8-9. In ID8-9, faunal remains disclose a good representation of open areas, and we should note that rabbits increase at this level. The dominance of open-dry small mammals indicates the dominance of an open landscape with sparse forests.

\section{Comparisons with large mammal fauna assemblages}

The large mammals (Cuenca-Bescós and García, 2007) of the Early Pleistocene levels of Gran Dolina (TD3-TD7) indicate a climatically variable episode that characterises the post-Jaramillo faunas. Both dry and wet open-country mammals are found in TD5, especially, TD5a-d (i.e., Equus altidens, Dama vallonnetensis, Eucladoceros giulii, Bison cf. voigtstedtensis, Cervus Elaphus, Crocuta crocuta, Ursus dolinensis, Vulpes praeglacialis, Homotherium latidens, Panthera gombaszoegensis and Sus scrofa). The $\mathbf{H}^{\prime}$ index for small vertebrates is lower here than in the following level TD6, and the changes are relatively more marked as well (TD5 and TD6 are similar in thickness, at roughly $2.5 \mathrm{~m}$ ). In TD6 a warmer and relatively wooded landscape may be represented by Canis mosbachensis, Mustela palerminea and Lynx sp., in addition to all the species registered in TD5. Nevertheless, the presence of Mammuthus sp. shows that open-country was also significant at this time, although the small vertebrates do not show any significant change, except in the upper part of TD6 (TD6-1, TD6-2 in Fig. 5). 


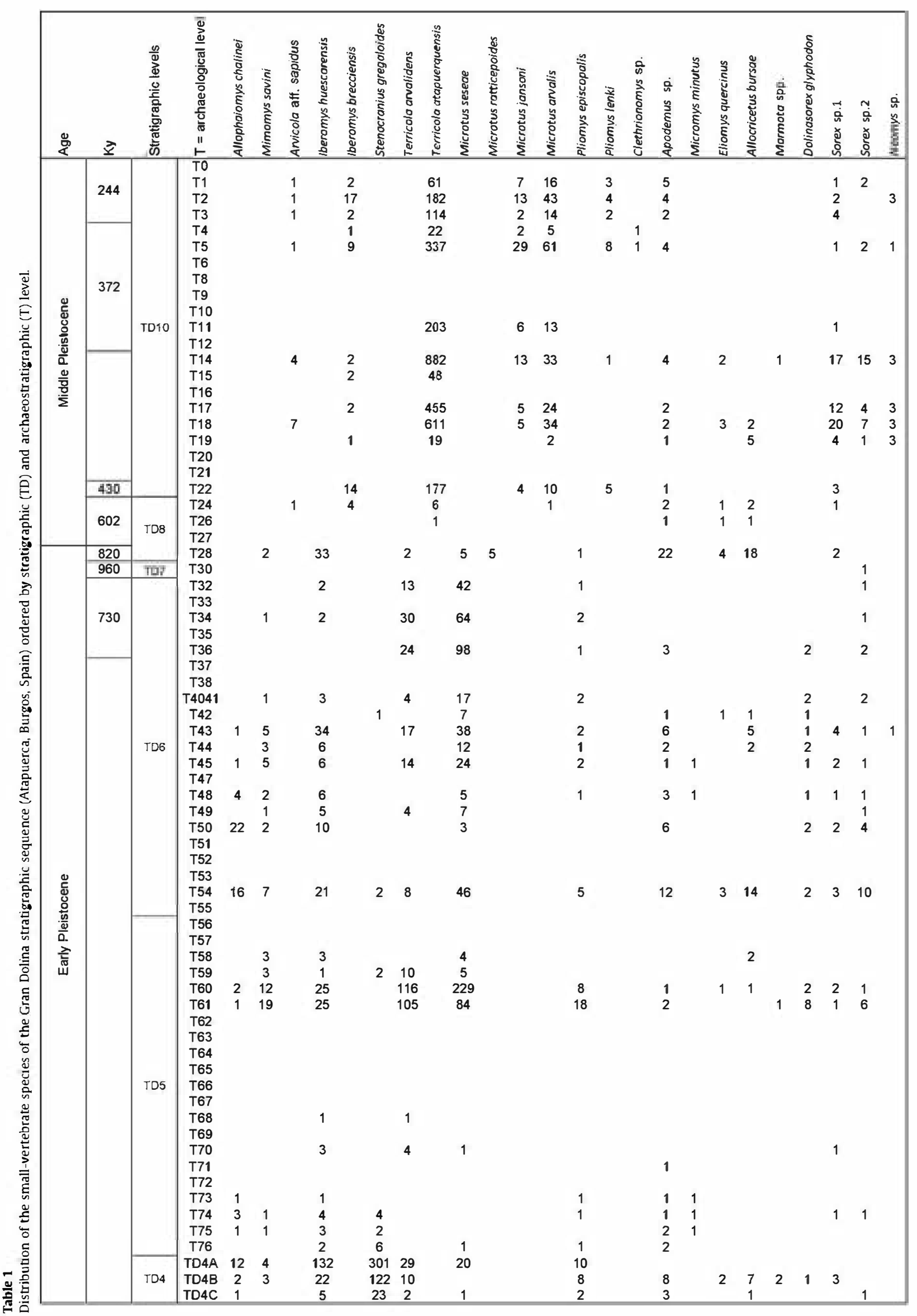




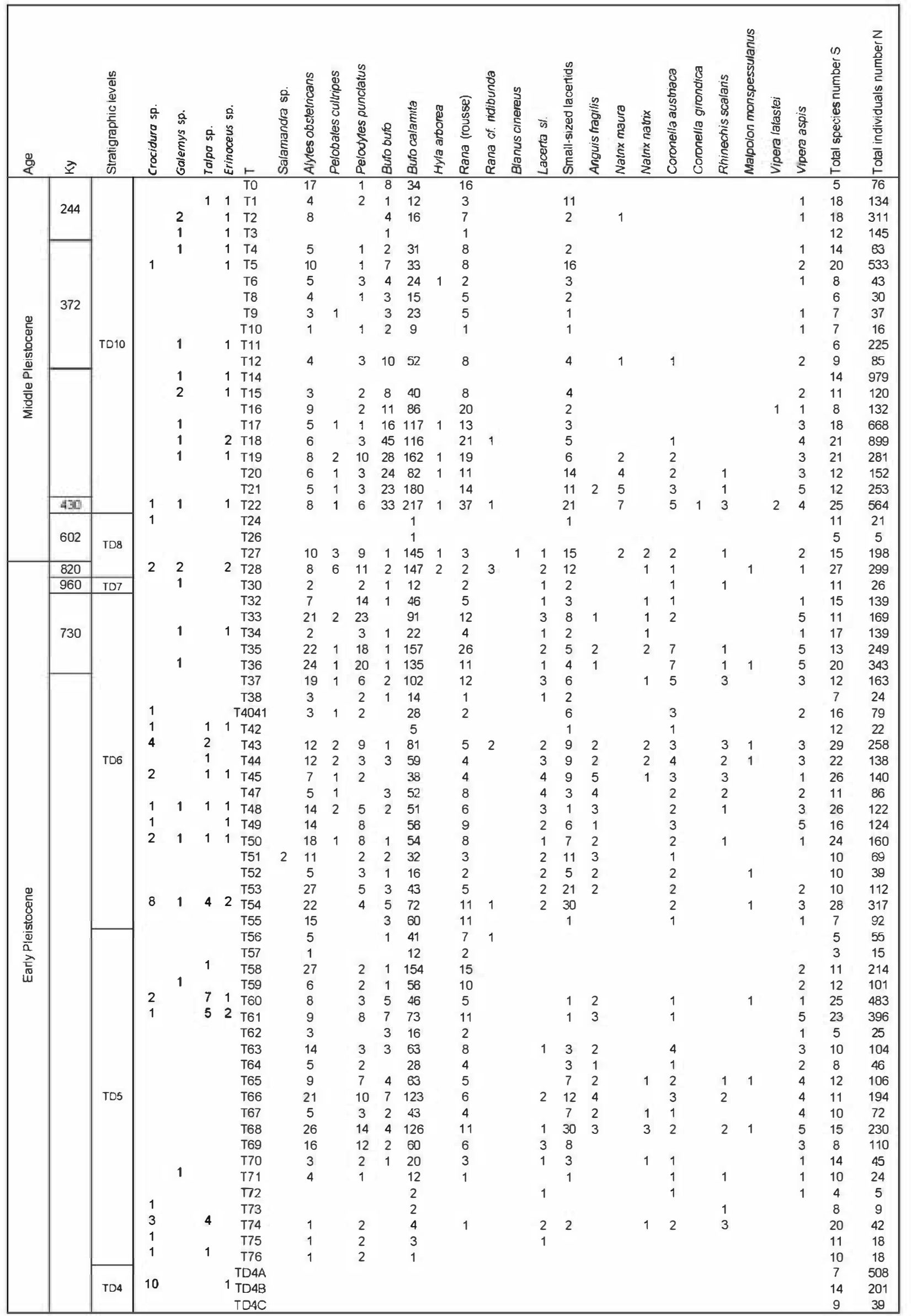


In level TD8, the presence of the porcupine (Hystrix) and the hippopotamus suggest a relatively warm and humid interval, just above the Matuyama-Brunhes transition. Levels TD8-9 and TD10 may represent a long and complex period with the climate alternating between warmer and cooler conditions (Cuenca-Bescós and García, 2007). The $\mathrm{H}^{\prime}$ index shows that levels TD8-9, TD10-4 and the bottom of TD10-3 have higher diversity and from here up there is a transition to lower d iversity (Fíg. 4), which recovers slightly at the end of the sequence (TD10-1).

\section{Comparison with the pollen assemblages of Gran Dolina}

The pollen and spores have been studied by García-Antón (1995, 1998). Here we summarize the pollen record of Gran Dolina for discussion with the results obtained through the study of the small vertebrates. The pollen record is scarce though present in some levels, thus allowing interpretation of the vegetation in TD.

Following García-Antón $(1995,1998)$ the pollen spectra from the TD generally indicate the presence of deciduous and evergreen Quercus. Conifers (Pimus) and Cupressaceae are important at some strata. In TD5 the tree pollen is predominantly that of Quercus. In the upper part of TD5, evergreen Quercus indicates more xeric conditions. In TD6 Cupressaceae, evergreen and deciduous Quercus and Olea are well represented, with Cupressaceae more abundant in the lower part. Quercus and Ericaceae íncrease from the bottom to top. suggesting that dry conditions gradually gave way to a moist situation. The presence of the pollen of Mediterranean taxa towards the top of TD6 suggests a temperate climate. This coincides with the Mediterranean character of Hystrix, also present here. Level TD7 includes less Cupressaceae than in the preceding levels, and Pimis together with Quercus, and Olea, Vitis and Fagus are the characteristic floral elements of this unit. García-Antón (1995, 1998) concluded that the contemporaneous climate indicated by these spectra was neither cold nor particularly temperate during TD7. This level displays the final "high peak" in $\mathrm{H}^{\prime}$ for amphibians and reptiles prior to their decrease towards the upper levels. Small mammals are too scarce on this level to be analysed.

The two pollen samples from TD8 include significant numbers of Castanea together with the usual Gran Dolina taxa: both types of Quercus and other taxa such as Betula, Acer, Almus, Hedera, Fagus, Salix and Ericaceae. Together they indicate warm, temperate and humid conditions. The woodland habitat index here shows the highest peak of the Gran Dolina sequence, also indicating wooded conditions. The $\mathrm{H}^{\prime}$ diversity index is also at one of its highest levels both for small mammals and for amphibians and reptiles and is the highest prior to its progressive decline towards Gran Dolina levels 8-9 and 10 (TD8-9 and TD10).

There is no pollen in level TD8-9. In TD10 pollen is present only at the lower part. Pimus is abundant while Mediterranean components (Olea) and temperate species (deciduous Quercus) are less abundant. This probably represents a transition to a cold phase (García-Antón, 1995). Our results are in accordance with this, since we found that the base of TD10 is more diverse in terms of its smallvertebrate contents than the middle part (TD10-3) though it seems to recover at the end of the TD10 sequence, TD10-2 and TD10-1 (Figs. 4,5).

\section{Comparison with the locality of Gesher Benot Ya'aqov}

The Early-Middle Pleistocene locality of Gesher Benot Ya'aqov shows alternating humid, dry, or cooler conditions at CBY. The isotopic studies of molluscs indicate that the EMP transition coincides with an environmental change from a relatively cold dry climate towards a warmer temperate subtropical climate above the MMB in GBY (Spiro et al., 2011). Although we have no fauna in common between the Gran Dolina and the GBY localities, it seems that the same pattern is shared in both sequences: the transition of slightly dry and cold conditions to warm and humid conditions just in the ca. $200 \mathrm{k.yr}$. of the EMP transition.

\section{Conclusions}

The evolution of the structure of the associations of small vertebrates (12,359 individuals distributed in 49 taxa) at the site of Gran Dolina in Atapuerca (Burgos, Spain) show important environmental and climatic changes in the EMP, ca. 800-600 ka. The comparison of the distribution of the Shannon index $\left(\mathrm{H}^{\prime}\right)$ calculated for the small-vertebrate taxa, with the data for the habitat distribution, large mammals and pollen of former studies, reveals that the environments fluctuated between warm and humid and cold and dry. Around the MMB paleomagnetic event there is a change from dry and cold to humid and warm conditions, whereas some $200 \mathrm{ka}$ after this limit there is a decline in humidity and wooded habitats towards the end of the Gran Dolina sequence. The final history of the faunal associations of the Gran Dolina section entailed an impoverishment of the species diversity, reflected in a decrease in Shannon's index not only for small mammals but for amphibians and reptiles as well. The peaks of $\mathrm{H}^{\prime}$ at the Gran Dolina sequence, are correlated with the marine isotopic stages (MIS), based on the assumptions that high $\mathbf{H}^{\prime}$ values are correlated with warm, humid MIS stages and low values correspond to dry, cold MIS. Some of these peaks are calibrated with radiometric, paleomagnetic and biostratigraphic dating.

The small-vertebrate fossil assemblages of the Gran Dolina section show a general trend towards the opening of the landscape slightly after the Early-Middle Pleistocene transition. In Gesher Benot Ya'aqov there is a pattern similar to Gran Dolina. The opening of the landscape could reflect the ideal conditions in which hominins expanded their territories from the south to the north and central Europe.

\section{Ackenowledgements}

We are grateful to several colleagues from the EIA team (Equipo Investigador de Atapuerca) for helpful discussions: Ana I. Ortega, Jesús Rodríguez, Andreu Ollé, Rosa Huguet, Jordi Rosell, Josep María Parés, Ruth Blasco, Alfredo Pérez-Conzález, Alfonso Benito, and Raquel Pérez. The Atapuerca excavation team helped with the extraction and sieving-washing labour of the sediments each year. Research and excavation was supported by the Junta de Castilla y León, projects DGI CGL2006-13532-C03-02, MICINN-CGI.200912703-C03-03, INAEM, Fundación Atapuerca, Fundación Duques de Soria, Grupos Consolidados 2007, 2008, 2009 del Gobierno de Aragón, and the University of Zaragoza. Particularly to the professor Naama Goren-Inbar and her team for their invitation to participate in the workshop "Climate change in the upper Jordan valley between ca. 800 and $700 \mathrm{ka}$ - its impact on the environment and hominins and its potential as a prediction for future scenarios" at the Hebrew University in Jerusalem during May 2009. The two reviewers and the editors have substantially improved the final draft of the manuscript.

\section{References}

Aguirre, E., 1995. Alapuerca (Burgos, España): su contribución a las ciencias del Cuaternario. Rey. Esp. Pal. 10, 58-82.

Aguirre, E., 2007. A apuerca (Burgos, Northern Spain) - potential, progress and questions. Cour. Forsch.-Inst. Senckenberg 259, 11-120.

Alcalde, G., Agusti, J., Villalta, J.F., 1981. Un nuevo Allophaiomys (Arvicolidae, Rodentia, Mammalia) en el Pleistoceno Inferior del sur de España. Acta Geol. Hisp. 16, 203-205. 
Almogi-Labin, A., 2011. The paleoclimate of the Eastern Mediterranean during the transition from early to mid Pleistocene (900-700 ka) based on marine and non-marine records: an integrated overview. J. Hum. Evol. 60 (4), 109-117

Alperson-Afil, N., Sharon, G., Kislev, M., Melamed, Y., Zohar, I., Ashkenazi, S., Rabinovich, R, Biton, R, Werker, E., Harman, G., Feibel, C., Goren-Inbar, N., 2009. Spatial organization of hominin activities at Gesher Benot Ya'aqov, Israel. Science 326, 1677

Arsuaga, J.L., Martínez, I., Gracia, A., Carretero, J.M., Lorenzo, C., García, N., Ortega, A.I., 1997. Sima de los Huesos (Sierra de Atapuerca, Spain). The site. J. Hum. Evol. 33, $109-127$.

Arsuaga, J.L., Gracia, A., Lorenzo, C., Martínez, I., Pérez, P.J., 1999a. Resto craneal humano de Galería/Cueva de los Zarpazos (Sierra de Atapuerca, Burgos). Memorias. Arqueología en Castilla y León 7, 233-235.

Arsuaga, J.L., Martinez, I., Lorenzo, C., Gracia, A., Muñoz, A., Alonso, •., Gallego, J., 1999b. The human cranial remains from Gran Dolina Lower Pleistocene site (Sierra de Atapuerca, Spain). J. Hum. Evol. 37, 431-457.

Arsuaga, J.L., Martínez, I., 2004. Atapuerca y la evolución humana. Fundació Caixa Catalunya 155.

Bailon, S., 1991. Amphibiens et reptiles du Pliocène et du Quaternaire de France et d'Espagne: mise en place et évolution des faunes. Unpublished PhD thesis, University of Paris VII, France.

Bailon, S., 1999. Différenciation ostéologique des Anoures (Amphibia, Anura) de France. In: Desse, J., Desse-Berset, N. (Eds.), Fiches D'ostéologie Animale Pour L'archéologie, Série C:varia. Centre de Recherches Archéologiques-CNRS, Valbonne.

Benito, A., 2004. Análisis geomorfológico y reconstrucción de paleopaisa jes neógenos y cuaternarios en la Sierra de Atapuerca y el valle medio del río Arlanzón. PhD. Dissertation, Universidad Complutense de Madrid

Benito-Calvo, A., Pérez-Gonzâlez, A., Parés, J.M., 2008. Quantitative reconstruction of Late Cenozoic landscapes: a case study in the Sierra de Atapuerca (Burgos, Spain). Earth Surf. Process. Landforms 33, 196-208.

Bennàsar Serra, M.L., 2010. Estudio tafonómico de los micromamíferos de los yacimientos del Pleistoceno Inf erior de los yacimientos de Gran Dolina y Sima del Elef ante. (Atapuerca, Burgos, Spain). PhD. Dissertation, Universitat Rovira i Virgili, Tarragona

Berger, G.W., Perez-Gonzalez, A., Carbonell, E., Arsuaga, J.L., Bermudez de Castro, J.-M., Ku, T.-L, 2008. Luminescence chronology of cave sediments at the Atapuerca paleoanthropological site, Spain. J. Hum. Evol. 55, 300-311.

Bermiı̂dez de Castro, J.M., Arsuaga, J.L., Carbonell, E., Rosas, A., Martinez, I. Mosquera, M., 1997. A hominid from the lower Pleistocene of atapuerca, Spain: possible ancestor to Neandertals and modern humans. Science 276, 1392-1395.

Bermîdez de Castro, J.M., Martinón-Torres, M., Carbonell, E., Sarmiento, S., Rosas, A., Van der Made, J., Lozano, M., 2004. The Atapuerca Sites and their contribution to the knowledge of human evolution in Europe. Evol. Anthropol. 13, 25-41.

Bischoff, J.L., Williams, R.W., Rosenbauer, R J., Aramburu, A., Arsuaga, J.L., García, N., Cuenca-Bescós, G., 2007. High-resolution U-series dates from the Sima de los Huesos hominids yields kyrs: implications for the evolution of the early Neanderthals. J. Archaeol. Sci. 34, 763-770.

Blain, H-A., 2005. Contribution de la Paléoherpétof aune (Amphibia et Squamata) à la connaisance de l'évolution du climat et du paysage du Pliocène supérieur au Pléistocene moyen d'Espagne. PhD. dissertation Muséum National d'Histoire Naturelle, Paris

Blain, H.-A., Bailon, S., Cuenca-Bescós, G., 2008. The Early-Middle Pleistocene palaeoenvironmental change based on the squamate reprile and amphibian proxies at the Gran Dolina site, Atapuerca, Spain. Palaeogeogr. Palaeoclimatol. 261, 177-192.

Blain, H.-A., Bailon, S., Cuenca-Bescos, G., Arsuaga, J.L., Bermudez de Castro, J.M., Carbonell, E., 2009. Long-term climate record inferred from early-middle Pleistocene amphibian and squamate reptile assemblages at the Gran Dolina Cave, Atapuerca, Spain. J. Hum. Evol. 56, 55-65.

Böhme, G., 1977. Zur Bestimmung quartärer Anuren Europas an Hand von Skelettelementen. Wissenschaftliche Z. Humbold-Universität Berlin, Math.-Nat. Reihe 36, 283-300.

Carbonell, E., Bermîdez de Castro, J.M., Arsuaga, J.L., Díez, J.C., Rosas, A., CuencaBescós, G., Sala, R, Mosquera, M., Rodríguez, X.P., 1995. Lower Pleistocene hominids and Artif acts from Atapuerca-TD6 (Spain). Science 269, 826-829.

Carbonell, E., Esteban, M., Martin Najera, A., Mosquera, M., Rodríguez, X.P., @llé, A., Sala, R, Vergés, J.M., Bermîdez de Castro, J.M., Ortega, A.I., 1999. The Pleistocene site of Gran Dolina, Sierra de Atapuerca, Spain: a history of the archaeological investigations. J. Hum. Evol. 37, 313-324.

Carbonell, E., Bermîdez de Castro, J.M., Arsuaga, J.L, Allue, E., Bastir, M., Benito, A Cáceres, I. Canals, T. Díez, J.C van der Made, J., Mosquera, M. @lle, A. PerezGonzalez, A., Rodriguez, J., Rodriguez, X.P., Rosas, A., Rosell, J., Sala, R, Vallverdu, J., Verges, J.M., 2005. An early Pleistocene hominin mandible from Atapuerca-TD6, Spain. Proc. Natl. Acad. Sci. U.S.A. 102, 5674-5678.

Carbonell, E., Bermîdez de Castro, J.M., Parés, J.M., Pérez-González, A., CuencaBescós, G., @llé, A., Mosquera, M., Huguet, R, van der Made, J., Rosas, A., Sala, R, Vallverdî. J., García, N., Granger, D.E., Martinón-Torres, M., Rodríguez, X.P. Stock, G.M., Vergès, J.M., Allué, E., Burjachs, F., Cáceres, I., Canals, A., Benito, A., Díez, C., Lozano, M., Mateos, A., Navazo, M., Rodríguez, J., Rosell, J., Arsuaga, J.L, 2008. The first hominin of Europe. Nature 452, 465-470.

Carretero, J.M., Lorenzo, C., Arsuaga, J.L., 1999. Axial and appendicular skeleton of Homo antecessor. J. Hum. Evol. 37, 459-499.

Chaline, J., 1972. Les rongeurs du Pleistocène moyen et supèrieur de France. Cahiers de Paléontologie, 1-410. C.N.R.S.
Cohen-Shlagman, L, Yom-Tov, Y., Hollwing, S., 1984. The biology of the Levant vole Microtus guentheri in Israel. I. Population dynamics in the Field. Z. Säugetier 49 135-147.

Colak, E., Sözen, M., Yigit, N., 1998. A study on ecology and biology of Microtus guentheri Danford and AIston, 1880 (Mammalia: Rodentia) in Turkey. Tr. J. Zool 22, 289-295.

Cuenca Bescós, G Canudo, J.1. Laplana Conesa, C 1998. Importancia biocronológica y paleoclimática de los roedores en los yacimientos de homínidos del Pleistoceno Inf erior y Medio de Atapuerca (Burgos). In: Aguirre, E. (Ed.), Atapuerca y la Evolución Humana. Fundación Ramón Areces, Madrid.

Cuenca-Bescós, G., 2003. The micromammal record as proxy of palaeoenvironmental changes in the Pleistocene of the Sierra de Atapuerca (Burgos, Spain). In: Blanca, M., Dorado, M., Valdelmillos, M.J., Gil, T., Bardaji, A., Bustamante, I. Martinez, I. (Eds.), Quaternary Climatic Changes and Environmental Crises in the Mediterranean Region. Universidad de Acalá de Henares, Madrid, pp. 133-138.

Cuenca-Bescós, G., Canudo, J.1., Laplana, C., 1995. Los Arvicólidos (Rodentia, Mammalia) de los niveles inferiores de Gran Dolina (Pleistoceno Inf erior, Atapuerca, Burgos, España). Rev. Esp. Pal. 10, 202-218.

Cuenca-Bescós, G., Laplana, C., Canudo, J.I., 1999. Biochronological implications of the Arvicolidae (Rodentia, Mammalia) from the lower Pleistocene hominid-bearing level of Trinchera Dolina 6 (TD6, Atapuerca, Spain). J. Hum. Evol. 37, 353-373.

Cuenca-Bescós, G., Canudo, J.1., Laplana, C., 2001. La séquence des rongeurs (Mammalia) des sites du Pléistocène inférieur et moyen d'Atapuerca (Burgos, Espagne). L'Anthropologie 105, 115-130.

Cuenca-Bescós, G., Rofes, J., García-Pimienta, J., 2005. Environmental change across the early-middle Pleistocene ransition: small mammalian evidence from the Trinchera Dolina cave, Atapuerca, Spain. In: Head, M.J., Gibbard, P.L. (Eds.), Early-Middle Pleistocene Transitions: The Land-acean Evidence. Geol. Soc. London Spec. Publ., 247, pp. 277-286.

Cuenca-Bescós, G., Straus, LG., González Morales, M.R, García Pimienta, J.C., 2008 Paleoclima y paisaje del final del cuaternario en Cantabria: los pequeños mamíferos del Mirón (Ramales de la Victoria). Rev. Esp. de Pal. 23, 91-126

Cuenca-Bescós, G., Straus, L.G. González Morales, M. García Pimienta, J.C., 2009. The reconstruction of past environments through small mammals: from the Mousterian to the Bronze age in el Miron cave (Cantabria, Spain). J. Archaeol. Sci. 36, 947-955.

Cuenca-Bescós, G., Rofes, J., López-García, J.M., Blain, A.H., De Marfá, J.R, GalindoPellicena, M.A., Bennàsar-Serra, M.L, Melero-Rubio, M., Arsuaga, J.L., Bermî́dez de Castro, J.M., Carbonell, E., 2010. Biochronology of Spanish Quaternary small vertebrate faunas. Quaterna. Int 212, 109-119.

Cuenca-Bescós, G., García, N., 2007. Biostratigraphic sucession of the early and middle Pleistocene mammal faunas of the Atapuerca cave sites (Burgos, Spain) CFS 259, 99-100.

Cuenca-Bescós, G., Rofes, J., 2007. First evidence of poisonous shrews with an envenomation apparatus. Naturwissenschaften 94, 113-116.

Esteban, M. Sanchiz, B., 1985. Herpetofauna de Erralla. Munibe 37, 81-86.

Esteban, M., Sanchiz, B., 1991. Sobre la presencia de Rana iberica en el Pleistoceno burgales. Rev. Esp. Herp. 5, 93-99.

Falguères, C., Bahain, J.J., Yokoyama, Y., Arsuaga, J.L, Bermı̂dez de Castro, J.M. Carbonell, E., Bischoff, J.L., Dolo, J.M., 1999. Earliest humans in Europe: the age of TD6 Gran Dolina, Atapuerca, Spain. J. Hum. Evol. 37, 343-352.

Fernández Jalvo, Y., Andrews, P., 1992. Small mammal taphonomy of Gran Dolina, Atapuerca (Burgos), Spain. J. Archaeol. Sci. 19, 407-428.

García-Antón, M., 1998. Reconstrucciones de Paleovegetación en Atapuerca segûn análisis polínico. Atapuerca y la Evolución Humana. In: Aguirre, E. (Ed.). Fundación Ramón Areces, Madrid, pp. 63-71.

García-Antón, M., 1995. Paleovegetación del Pleistoceno Medio de Atapuerca a través del análisis polínico. In: Bermûdez de Castro, J.M., Arsuaga, J.L., Carbonell, E (Eds.). Evolución humana en Europa y los yacimientos de la Sierra de Atapuerca. Human evolution in Europe and the Atapuerca Evidence. Workshop Castillo de la Mota, Medina del Campo, Valladolid. Junta de Castilla y León Consejería de Cultura y Turismo, Valladolid.

Gleed-owen, C.P., 2000. Subf ossil records of Rana cf. lessonae, Rana arvalis and Rana cf. dalmatin from Middle Saxon (c. 600-950 AD) deposits in eastern England: evidence for native status. Amphibia-Reptilia 21 (1), 57-65.

Goren-Inbar, N., Feibel, C.S., Verosub, K.L., Melamed, Y., Kislev, M.E., Tchernov, E Saragusti, I., 2000. Pleistocene milestones on the out-of-Africa corridor at Gesher Benot Ya'aøov, Israel. Science 289, 944-974.

Hammer, ø., Harper, D.A.T., Ryan, P.D., 2001. PAST: paleontological statistics soft ware package for education and data analysis. Pal. Electr. 4, 1-9.

Holman, J.A., 1998. Pleistocene Amphibians and Reptiles in Britain and Europe. oxford Monographs on Geology and Geophysics. Oxford University Press, New York and Oxford

Huguet Pàmies, R, 2007. Primeras occupaciones humanas en la Península Ibérica: Paleoeconomia de la Sierra de Atapuerca (Burgos) y la Cuenca de Guadix-Baza (Granada) durante el Pleistoceno Inf erior. Ph.D. dissertation, Universitat Rovira Virgili, Tarragona.

LópezAntoñanzas, R, Cuenca-Bescós, G, 2002. The Gran Dolina site (lower to middle Pleistocene, Atapuerca, Burgos, Spain): new palaeoenvironmental data based on the distribution of small mammals. Palaeogeogr. Palaeoclimatol. 186, 311-334.

López-García, J.M., 2008. Evolución de la diversidad taxonómica de los micromamíferos en la Península Ibérica y cambios Paleoambientales durante el Pleistoceno Superior. PhD. Dissertation, Universitat Rovira i Virgili, Tarragona.

Martinez, I., Rosa, M., Arsuaga, J.-L., Jarabo, P., Quam, R. Lorenzo, C., Gracia, A Carretero, J.M., Bermîdez de Castro, J.-M., Carbonell, E., 2004. Auditory 
capacities in Middle Pleistocene humans from the Sierra de atapuerca in Spain. Proc. Natl. Acad. Sci. U.S.A. 101 (27), 9976-9981.

McCain, C.M., 2004. The mid-domain effect applied to elevational gradients: species richness of small mammals in Costa Rica. J. Biogeogr. 31, 19-31.

van der Meulen, A.J., 1973. Middle Pleistocene smaller mammals from the Monte Peglia (Orvieto, Italy) with special reference to the phylogeny of Microtus (Arvicolidae, Rodentia). Quaternaria 17, 1-144.

Ortega Martínez, A.I., 2009. Evolución geomorfológica del Karst de la Sierra de Atapuerca (Burgos) y su relación con los yacimientos pleistocenos que contiene. PhD. Dissertation, Universidad de Burgos.

Parés, J.M., Pérez-González, A., 1995. Paleomagnetic age for hominid fossils at Atapuerca archaeological site, Spain. Science 269, 830-832.

Pokines, J.T., 1998. The paleoecology of lower Magdalenian Cantabrian Spain. Bar Int. Ser. 713, 1-189

Rabinovich, R, Gaudzinski-Windheuser, S., Goren.Inbar, N., 2008. Systematic butchering of fallow deer (Dama) at the early middle Pleistocene Acheulian site of Gesher Benot Ya'aqov (Israel). J. Hum. Evol. 54, 134-149.

Rofes, J., Cuenca-Bescós, G., 2009a. A new genus of red-toothed shrew (Mammalia Soricidae) from the early Pleistocene of Gran Dolina (Atapuerca, Burgos, Spain), and a phylogenetic approach to the eurasiatic Soricinae. Z.J. Linnean Soc. 155, 904-925.

Rofes, J., Cuenca-Bescós, G., 2009b. First record of Beremendia fissidens (Mammalia, Soricidae) in the Pleistocene of the Iberian Peninsula, with a review of the biostratig raphy, biogeography and palaeoecology of the species. C.R. Palevol. 8, 21-37.
Rowe R.J., 2009. Environmental and geometric drivers of small mammal diversity along elevational gradients in Utah. Ecography.

Shannon, C.E., Weaver, W., 1949. The Mathematical Theory of Communication. University of Illinois Press, Urbana.

Sharon, G., Alperson-Afil, N., Goren-Inbar, N., 2011. Cultural conservatism and variability in the Acheulian sequence of Gesher Benot Ya'aqov. J. Hum. Evol. 60 (4), 68-78.

Spiro, B., Ashkenazi, S., Mienis, H.K., Melamed, Y., Feibel, C., Delgado, A., Starinsky, A., 2009. Climate variability in the Upper Jordan Valley around $0.78 \mathrm{Ma}$, inferences from ime-series stable isotopes of Viviparidae, supported by mollusc and plant palaeoecology. Palaeogeogr. Palaeoclimatol. 282, $32-44$.

Spiro, B., Ashkenazi, S., Starinsky, A., 2011. Chemical and isotopic composition of Melanopsis and ambient waters in the Hula Basin, Upper Jordan Valley. J. Hum. Evol. 60 (4), 88-97.

Szyndlar, Z., 1984. Fossil snakes from Poland. Acta Zool. Crac. 28, 1-156.

Torres, T., 1988. Ursidos del Pleistoceno-Holoceno de la Península Ibérica. In: Instituto Geologico y Minero de España Pub. Spec., pp. 1-314.

Vergés, J.M., Allué, E., Angelucci, D., Cebrià, A., Díez, C., Fontanals, M., Manyanòs, A., Montero, S., Moral, S., Vaquero, M., Zaragoza, J., 2002. La Sierra de Atapuerca durante el Holoceno: datos preliminares sobre las ocupaciones de la Edad del Bronce en la cueva de El Mirador (Ibeas de Juarros, Burgos). Trabajos de Prehistoria 59, 107-126. 